Zoltán B. Nagy, Ph.D., Associate Professor

University of Miskolc

Faculty of Law

jogdrnz@uni-miskolc.hu

\title{
THE HUNGARIAN TAX REGULATION ON THE LAND AND AGRICULTURAL ACTIVITY ${ }^{1}$
}

\begin{abstract}
This study examines the Hungarian tax law regulations regarding agricultural activities and the tax law status of arable land. The examination focuses on three tax categories since the scope of this study does not make it possible to perform a thorough examination of all the tax categories as well as these three tax categories focus the most on the special status of arable lands and food production. The three tax categories - Personal Income Tax, Value Added Tax and Levy-depict the sector's tax law specialties. The most significant regulations can be found on the field of Personal Income Tax since rhis tax category offers possibilities to diversely regulate the agricultural activities. The Value Added Tax and Levy mostly helps the agricultural activities with special regulations, tax exemptions and tax benefits.
\end{abstract}

Keywords: tax, Personal Income Tax, Value Added Tax, Levy, agricultural entrepreneur, small-scale agricultural producer, tax exemption, tax benefits.

\section{INTRODUCTORY THOUGHTS}

The legal literature regarding the agrarium considers tax law regulations as a part of the so called agricultural financial law'. According to Ede János Szilágyi „the two big parts of the agricultural financial system are agricultural taxing and agricultural financing ,The agricultural financing as a part can be further separated into special agricultural loan and agricultural financial aid. ${ }^{2}$ It must be

${ }^{1}$ The described article was carried out as part of the EFOP-3.6.1-16-2016-00011 "Younger and Renewing University - Innovative Knowledge City - institutional development of the University of Miskolc aiming at intelligent specialisation" project implemented in the framework of the Szechenyi 2020 program. The realization of this project is supported by the European Union, cofinanced by the European Social Fund.

${ }^{2}$ Szilágyi János Ede: Agricultural and rural development finances and agricultural risk management rules, in: Szilágyi János Ede (SZERK.): Agrárjog. Miskolc, 2017, Miskolci Egyetemi Kiadó, 236-237.P. 
noted that the state's role is significant not only related to agricultural taxing but at the other two parts of agricultural financing though this role's effect varies greatly. Regarding the agricultural loan Csilla Csák notes that , the state's presence takes place in establishing and operating the loaning system depending on how the sector's profitability and the bank's loaning costs relate to each other... [;] in our country ... the financing and within it the loaning system's establishing, as well as establishing and operating the agricultural financing all presume the neccessity of the state's intervention. ${ }^{3}$ Regarding the agricultural financial aid similar to other countries of the European Union - the defining role is not the member state's but the European Union's since ,after joining the European Union the role of national financial aid underwent a significant change, manifesting in a smaller amount than that of agricultural- and regional development aid financed by the European Union." ${ }^{\prime 4}$ Focusing to the basics by Csaba Lentner in agriculture we find long production processes, high capital requirements, strong fluctuations of earnings, becasue of the sector depend on special biological factors, climate and weather, so goverments and banks use special financing, support and tax policies. ${ }^{5}$

Regarding the agricultural taxing it can be determined that the Hungarian tax law regulations treat agricultural activities and arable lands as well as similar taxable persons in a special way. We can find significant differences in the regulations of different tax categories since each tax law treats this field differently due to its own nature. Generally speaking most tax laws aim for its regulations to be as general as possible and to enforce fair competition. ${ }^{6}$ In addition to these the

${ }^{3}$ Csák Csilla: International models of the agriculture institutional system, in: Csák Csilla (SZERK.) : Ünnepi tanulmányok Prugberger Tamás Professzor 70. születésnapjára. Miskolc, 2007, Novotni alapítvány, 83. P.

${ }^{4}$ Szilágyi (2017): Op. cit. 238. p.

${ }^{5}$ Lentner, Csaba: Dilemmas of Hungary's Agricultural Future Contrasted with Historical Backrground and Developed Market Economy Models. In. On the Eve of the 21st Century: Challenges and responses. Edited by Erzsébet Gidai, Budapest, 1998., Akadémiai Publishing House, pp. 175-185., Lentner, Csaba: Az agrárfinanszírozás kérdőjelei Magyarországon: az Amerikai Egyesült Államok, Kanada, Új-Zéland követhető modellek? In. Gazdálkodás, 1992, 36. évfolyam, 2. szám, pp. 70-72., Lentner, Csaba: A magyar agráfinanszírozás jellemzői az EU csatlakozás küszöbén. In. Gazdálkodás, 2004., 48. évfolyam, 1. szám, pp. 69-78., Lentner, Csaba: Magyar mezőgazdaság a pénzügypolitika csapdájában: A mezőgazdaság európai uniós támogatási rendszerének kritikája. In. Fejlesztési stratégiák, Finanszírozási Alternatívák. Edited by Katona, Klára - Schlett, András, 2014. Pázmány Press, pp. 247-261.

${ }^{6}$ In Hungary, the ownership-acquisition of agricultural lands is limited. See: Csilla Csák Bianka Enikő Kocsis - Anikó Raisz, Vectors and indicators of agricultural policy and law from the point of view of the agricultural land structure. Journal of Agricultural and Environmetal Law, 2015, 19. szám, 32-43. p. Zsófia Hornyák, Die Voraussetzungen und die Beschränkungen des landwirtschaftlichen Grunderwerbes in rechtsvergleichender Analyse, CEDR Journal of Rural Law, 2015, 1. szám, 91-97. p. Jakab Nóra - Szilágyi János Ede: New tendencies in connection with the legal status of cohabitees and their children in the agricultural enterprise in Hungary. Journal of Agricultural and Environmetal Law, 2013, 15. szám, 52-57. Olajos István: Die Entscheidung des 
legislator prefers those taxable persons who engage in agricultural activities or are owners of arable lands. ${ }^{7}$ The legislator took into account the sector's special qualities; the sector's great costs, receipt for these costs is not always available (self-employment, using self-producted materials), a big part of the taxable persons engage in agricultural activities as additional activity so the income from these activities is negligible, the sector requires high amount of tools and is time-consuming, investments pay off in a longer run; the state considers this sector a significant, strategic one so it does not subject great taxes to nor the one engaging in agricultural activities, nor the consumer (apart from excise goods). Regarding the definition of agricultural activities Csilla Csák notes that in the European Union the task of determining this definition is in the member state's authority, accordingly ,the definition of agricultural activity is not uniform in the member states. In Hungary it is defined in single legislative processes, from the visual angle of domains of regulation. According to this from different aspects, different definiteness can be observed, for example: tax law, environmental protection, support, land-property etc." 8

In the light of the above the tax law seeks to place the sector in a vantage point with its own devices. Such tools can be providing certain taxable persons special tax arrangements and legal status, providing special tax arrangements for products produced by agricultural activities and for the activity itself, defining

Verfassungsgerichts über die Rolle, die Entscheidungen und die Begründetheit der Gründen der Stellungnahmen der örtlichen Grundverkehrskommissionen, Agrar- und Umweltrecht, in press. Raisz Anikó: Topical issues of the Hungarian land-transfer law. CEDR Journal of Rural Law, 2017, 1. szám, 70-72. p. Szilágyi János Ede: Acquisition of the ownership of agricultural lands in Hungary, taking the EU's and other countries' law into consideration, Zbornik Radova Pravni Fakultet Novi Sad, 2016, 4. szám, 1444-1448. p.; Szilágyi János Ede: Das landwirtschaftliche Grundstückverkehrsgesetz als erster Teil der neuen ungarischen Ordnung betreffend landwirtschaftlichen Grundstücken, Agrar- und Umweltrecht, 2015, 2. szám, 46-50. p.

7 Csák Csilla: The Hungarian National Report on the legal forms of agricultural undertakings, with attention to traditional and industrial cultivation. Journal of Agricultural and Environmetal Law, 2010, 8. szám, 21. p.; Csilla Csák's statement does not contradict Ede János Szilágyi's observation, that the „European Union's regulations provide a definition of agricultural activities; Szilágyi János Ede: Változások az agrárjog elméletében? Miskolci Jogi Szemle, 2016, 1. szám, 38. p. Ede János Szilágyi did the thorough analysis of the changes of the definition of agricultural studies in the light of the relevant legislation and case law: Szilágyi János Ede: The Dogmatics of Agricultural Law in Hungary from an Aspect of the EC Law. European Integration Studies, 2009, 1. szám, 48-49. p.; Szilágyi János Ede: Az agrárjog dogmatikájának új alapjai - útban a természeti erőforrások joga felé? Jogtudományi Közlöny, 2007, 3. szám, 118-119. p.

${ }^{8}$ Regarding the evaluation of tendencies of agricultural tax law see István Olajos- Anikó Raisz: The Hungarian National Report on Scientific and Practical Development of Rural Law in the EU, in States and Regions and in the WTO. Journal of Agricultural and Environmetal Law, 2010, 8. szám, 45-46. p.; Szilágyi János Ede: The Hungarian National Report on Legal Incentives and Legal Obstacles to Diversification for Farmers. Journal of Agricultural and Environmetal Law, 2010, 8. szám, 11-12. p. 
separate tax rates, providing tax exemptions, the imposition of tax-deductible discounts and the provision of tax benefits.

The scope of the study does not allow it to analyze all the tax categories related to agricultural law, thus I will touch upon three tax categories - Personal Income Tax, Value Added Tax and Levy - outlining their cardinal points. At the same time, I must note that the Hungarian agricultural literature (Raisz-Szilágyi) has already paid special attention to corporate tax, but its importance is less relevant with regard to its specialties. The study only covers Hungarian legal regulation.

\section{SPECIAL REGULATIONS OF THE PERSONAL INCOME TAX RELATED TO AGRICULTURAL ACTIVITIES AND ARABLE LANDS}

From an agricultural law perspective the personal income tax addresses the sector's issues the most. Most private individuals perform agricultural cultivation not as a private entrepreneur but as an additional source of income which is especially important for the people living in rural areas. The sector's other particularity is their high cost and their questionable verification. Even though the agriculture as a sector demands great costs, these costs manifest in self-performed tasks or self-producted crop, actions which the taxpayer does not have bills for.

In the light of the above, the Act CXVII of 1995 on Personal Income Tax specially addresses the income of those private individuals who perform agricultural cultivation. The aforementioned law establishes the category of small-scale agricultural producers as well as agricultural smallholders, defines tax exemptions as well as provides discounts on income, establishes special small-cale agricultural flat-rate costs, provides tax relief for small-scale agricultural producers, and as a special tax rule it creates the option of flat-rate taxation.

The Act CXVII of 1995 on Personal Income Tax defines such incomes which can be disregarded when determining earnings. ${ }^{9}$ These are called non-taxable items, within its regulations the aforementionted Act regulates tax-free incomes. ${ }^{10}$ There are several tax exemptions related to the agricultural area, such as the income from the transfer of a cooperative business share obtained in the course of the realization of the cooperative business, the annuity obtained for land, the income from the transfer and lease of land, and the payment of land. It is also clear from the list that tax law exempts land income in particular from personal income tax.

The Act provides tax exemption up to a maximum of 10000 HUF for pensioners for the income received by a retired member of a cooperative from the

${ }^{9}$ Szakács Imre: Az adózás nagy kézikönyve. Budapest, 2008, KJK-Kerszöv, 772-775. p.

${ }^{10}$ Act CXVII of 1995 on Personal Income Tax . 7. § (1) a., and Schedule No 1. to Act CXVII of 1995 
transfer of his business share in the cooperative acquired as an allocated asset as part of a life annuity contract concluded with the cooperative in which he/she is a member, ${ }^{11}$ Similarly income received under a life-annuity contract concluded pursuant to the Act on National Land Reserves and the Government Decree on the Purchase of Arable Land by the State in Exchange for Life Annuity. ${ }^{12}$

Another preferred area of income from land is tax exemption for income from land transfer and leasing. The Act contains strict requirements as a condition of exemption, ${ }^{13}$ By principle only income below 200,000 HUF is tax-free for the sale of agricultural land if the buyer uses the agricultural land for a period of at least 5 years as a private entrepreneur or sells the land to a registered agricultural cooperative so the agricultural cooperative can rent the land for at least 10 years. The income is also tax-exempt if the transfer is made to a private individual for land consolidation purposes or municipal government for a social land program specified in a separate law or for the benefit of the National Land Fund..$^{14}$

It is important to also point out that if a private individual sells the arable land to private entrepreneur engaged in animal husbandry, or to a small-scale agricultural producer and they use it for at least 5 years, or sells it to an employee of a agricultural cooperative and the cooperative rents the land for at least 10 years, the income is tax-free regardless of the income limit. This type of total tax exemption applies when the share ownership is terminated and for the purpose of land consolidation, as well as for the benefit of the National Land Fund.

The proceeds from the leasing of the land will be tax-exempt if the lease term is five years on the basis of the contract based on the lease of the land. If the contract is terminated without a reason beyond the contracting parties, the taxpayer must pay the tax with interest.

The tax exemption for land allocation concerns the narrower range of private individuals. The Act provides tax exemption for land not exceeding 6,000 m2..$^{15}$

While ensuring the tax exemption, the personal income tax law provides favorable taxing conditions for taxpayers engaged in agricultural activities. ${ }^{16}$

Specific rules apply to small-scale agricultural producers and agricultural smallholders, the rules which apply to agricultural producers also apply to family estate farmers and their contributing family members and extend to the private

${ }^{11}$ Schedule No 6. to Act CXVII of 1995. 7.1.

12 Schedule No 1. to Act CXVII of 1995 7.14. The definition of arable land is not defined separately by the law, but it makes a refererence in paragraph 3, point 51, that agricultural and forestry land is defined in the Act CXXII of 2013 as arable lands.

${ }^{13}$ Schedule No 6. to Act CXVII of 1995. 9.5.1.-9.5.4. pont.

${ }^{14}$ Act LXXXVII of 2010 The National Land Fund is part of state treasury assets, and aims to manage the land owned by the state. This includes all land owned by the state and the related property rights.

${ }^{15}$ Schedule No 1. to Act CXVII of 1995 8.12., 8.13.

${ }^{16}$ Szakács (2008): Op. cit. 762. p. 
individuals who engage in agricultural production and are registered in the customer registration system maintained by the agricultural and regional development aid.

Small-scale agricultural producer ${ }^{17}$ means a private individual above the age of 16 who is not a private entrepreneur but possesses a small-scale producer license and is engaged in activities aimed at producing the listed products on his own farm.

Own farm shall mean the entitlement of the private individual who is actually conducting the production activities to dispose over the equipment (including leased equipment), the organization of production and - with the exception of cultivating sowing seeds under contract and breeding, fattening, and tending livestock under contract - the use of the results of production. ${ }^{18}$

Tax law also provides the definition of small-scale producer license: smallscale producer license means an official document issued and validated pursuant to the provisions of a government decree designed to register the income generated by small-scale agricultural activities; the license shall contain: a) the particulars of the small-scale agricultural producer, b) all of the other information prescribed in the government decree that is necessary for discharging tax liability. ${ }^{19}$

According to the personal tax law special taxation conditions are granted only to private individuals engaged in agricultural production, an important element of the concept of small-scale agricultural producer is the activity or the product to which this activity is directed.

Small-scale agricultural production activities include the growing of plants, orchards, breeding of animals, and processing of products at an individual's farm, if this occurs using base materials which are themselves produced at the farm, the collection of certain agricultural products at an individual's own farm which does not violate the law, and forestry activities conducted in an individual's own forest area, if, in respect of all of the aforementioned activities, the product produced or the activity falls under either of the categories listed in Act CXVII of 1995 on Personal income tax law. ${ }^{20}$

The concept of agricultural smallholder covers a narrower concept within the concept of a small-scale agricultural producer. Agricultural smallholder means any small-scale agricultural producer whose revenue from such activities does not exceed 8 million forints - 26230 euro - in a tax year. The special category is important because it provides better tax conditions for the individual.

The income from small-scale agricultural producer activities is one type of income derived from self-employment activities ${ }^{21}$ within the aggregate taxed

${ }^{17}$ Hadi László (szerk.): Az új adójog magyarázata 2010. Budapest, 2010, HVG-ORAC Kft., 871. p.; Act CXVII of 1995 on Personal Income Tax 3. § 18.

${ }^{18}$ Act CXVII of 1995 on Personal Income Tax 3. § 18. a.

${ }^{19}$ Act CXVII of 1995 on Personal Income Tax 3. §. 18. b.

${ }^{20}$ Schedule No 6. to Act CXVII of 1995.

${ }^{21}$ Act CXVII of 1995 on Personal Income Tax 8. §. The rate of tax in the year of 2017 is $15 \%$, in principle, for all income subject to personal income tax. 
earnings, so income is determined by itemized expense accounting or 10 per cent expense ratio. ${ }^{22}$

Small-scale agricultural producers (including agricultural smallholders using flat-rate taxation) with revenues less than 600,000 forints annually from such activities shall not be required to consider income from such revenues, while if revenues exceed the above amount, income shall be determined based on all revenues included. ${ }^{23}$

Small-scale agricultural producers using itemized expense accounting may deduct the following from their income from such activities ${ }^{24}$ : a) if employing workers with at least 50 per cent disability, the monthly wages paid to each such employee, not to exceed the prevailing monthly minimum wage in effect on the first day of the month; with respect to apprentice training of vocational school students on the basis of apprenticeship agreement, as described by law, 24 per cent of the prevailing minimum wage for each student and for the month and any fraction thereof, or 12 per cent of the prevailing minimum wage for the month and any fraction thereof if the apprentice training is provided under a cooperation agreement concluded with the vocational school. A small-scale agricultural producer (for the purposes of this Section hereinafter referred to as ,employer') providing further and continuous employment to a vocational school graduate who has successfully completed the professional examination or to a previously unemployed person, or a person released from imprisonment within 6 months from the date of release, or a person released on parole, if not using flat-rate taxation, may deduct the amount of social security contribution paid during such employment, not to exceed a period of 12 months, from the revenues produced by such activities, regardless of whether such amounts can otherwise be claimed as expenses in the case of itemized expense accounting.

Agricultural smallholders using itemized expense accounting may claim 40 per cent of the revenues from such activities, deducted as smallholders' expense allowance, over and above verified expenses. In this case losses may not be deferred until, if so intended, such smallholders' expense allowance is claimed. ${ }^{25}$

In addition to the special cost accounting and income reduction rules, the legislator also provides the taxpayer with a tax break for the small-scale

${ }^{22}$ Itemized cost accounting means that the taxpayer is entitled to deduct from his income the maximum amount of his income. 'Expense' according to Act CXVII of 1995 on Personal income tax 4. § (3); Only expenses directly connected to gainful activities, actually paid during the tax year exclusively for the purpose of gainful activities and for pursuing the activities, which are duly substantiated shall be recognized as expenses.

${ }^{23}$ Act CXVII of 1995 on Personal Income Tax 23. §.

${ }^{24}$ Act CXVII of 1995 on Personal Income Tax 21. §.

${ }^{25}$ Act CXVII of 1995 on Personal Income Tax 22. § (6) 
agricultural producer in the amount corresponding to the tax on his income from this activity, ${ }^{26}$ but this amount can not exceed 100,000 forints ( 327 euros). The two tax breaks are collectively referred to as small-scale agricultural producers' tax breaks.

Furthermore, the law also favors agricultural smallholders by giving them the option of flat-rate taxation which in essence means that no substantive cost declaration has to be made instead it is based on the smallholders income. ${ }^{27}$ The basis is the flat-rate income which is calculated by subtracting the expense ratio determined by the Personal Income Tax and expressed in a precentage of income Act from the smallholders overall income. ${ }^{28}$

This results in an extremely low tax base for agricultural smallholders, generally $15 \%$ (expense ratio of $85 \%$ ) and $6 \%$ for breeding and production of animal products (expense ratio of $94 \%$ ).

Agricultural activities may be conducted by the taxpayer as a private entrepreneur as well but in this case he shall be subjected to the general rules with the exception of flat-rate taxation since that is also an option for private entrepreneurs conducting non-agricultural activites.

Special legislation has been in the Personal Income Tax Act within income from property transfer proceeds from the transfer of property reclassified agricultural land. By building residential parks, more and more land is being constructed so that land is extracted from agricultural cultivation and investors re-classify it as building land. This process jeopardizes the amount of arable lands, on the other hand, investors can gain extra profit as they can earn a substantially higher price for building land. The process has also attracted the attention of the legislator and has therefore introduced rules for taxing the extra profits. ${ }^{29}$ The law does not increase the tax rate, but sets special rules for its tax base and as the tax base increases, the amount of tax will also increase. In this case, the tax base is the usual return (the portion of the income that exceeds the deductible costs) and the amount exceeding the normal return threefold. Thus, the standard rate of the tax base is increased by three times the extra profit. This rule also applies where the taxable person sells his share in a company which has property and the shareholder obtains a foreign exchange gain. In this case, the tax base will be the normal amount and twice the amount gained from the exchange rate. ${ }^{30}$

\footnotetext{
${ }^{26}$ Act CXVII of 1995 on Personal Income Tax 39. § (1), Szakács (2008.): Op. cit., 852-853. p.

${ }^{27}$ Act CXVII of 1995 on Personal Income Tax 50-57. §

${ }^{28}$ Act CXVII of 1995 on Personal Income Tax 53. $\S$

${ }^{29}$ Act CXVII of 1995 on Personal Income Tax 62/A§.

${ }^{30}$ Szokásos hozam az Szja törvény alapján az ingatlan átruházás esetén a levonható költségek 0,3 százalékának a tulajdonban tartás naptári napjaival megszorzott összege.
} 


\section{SPECIAL REGULATIONS OF THE VALUE ADDED TAX RELATED TO AGRICULTURAL ACTIVITIES AND ARABLE LANDS}

Act CXXVII of 2007 (VAT Act) contains regulations on Value Added Tax specific to the different types of taxes. VAT is by definition a general, consumer-type tax. ${ }^{31}$ General, because - with certain exceptions - it applies to the sales and import of every product and service including acquisitions within the borders of the European Union. Consumer-type, because ultimately it weighs on the consumer or the end user.

There are no specific requirements toward taxable persons: the VAT applies to every person or organisation with legal capacity conducting economic activities with no regard to its location, aim or result. Economic activity shall mean a longterm, regularly conducted activity within the framework of business operations with the objective of or resulting in financial profits including especially agricultural activities. ${ }^{32}$

A wide range of bases of assessment are regulated by the VAT Act, its scope covers the inland sales of products and providing services, product import and product acqusition within the European Community. ${ }^{33}$

VAT is sectorneutral, the agricultural sector is also subject to the general rules and the law only mentions agricultural products and agricultural activites in special exceptions. The VAT Act regulates the agricultural sector with its participants and the consumers of agricultural products through special provisions.

This specialty manifests in the tax rates and the special legal status of agricultural producers.

The rate of VAT affects the consumer price of products putting the burden on the end consumers. Providing tax benefits for basic food products is in some cases necessary for the central budget to prevent them from becoming impossible to pay for by low income consumers.

The Act defines three types of tax rates. ${ }^{34}$ The general tax rate of $27 \%$ and the reduced rates of $5 \%$ and $18 \%$. These rates apply to different types of products and services. The general rate isn't specified by the Act, it is a collective rate which has to be applied to each transaction for which the legislator doesn't provide reduced tax rates. ${ }^{35}$

The 5\% tax rate apply to herbal drugs and among others to domestic swine, cattle, sheep, goat and their meat, poultry meat eggs and milk. The $18 \%$ tax rate

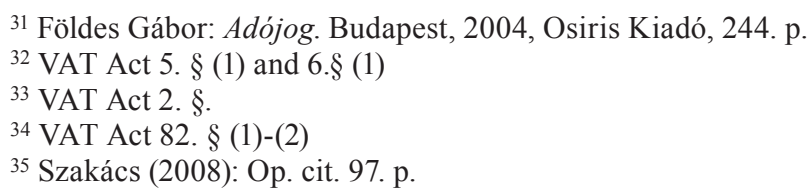


applies to milk products, grain and products made using these. Reduced tax rates therefore apply only to a limited circle of agricultural products.

Tax exemption is, however, more beneficial for the end consumer since VAT won't be applied and therefore won't be present as a price increasing factor. It is also favorable for low-income taxpayers since it exempts them from certain tax obligations and administrative burdens. Tax exemption is a special form of tax reduction. Generally there are two types of exemptions in tax law: personal and subject-based exemptions. ${ }^{36}$ VAT uses similary categories with the addition of inland sales and transportation since Hungary joining of the European Union.

In the case of personal exemptions legal requirements have to be met to be granted exemption. It is favorable since it exempts the taxable person from administrative burdens and certain tax obligations. Taxable persons choosing personal exemption are for instance not obligated to pay VAT. Furthermore it is important to highlight the taxable persons inability to exercise his right of tax deduction while under the cover of personal exemption. ${ }^{37}$ (This is not always financially favorable for the taxable person since he won't be entitled to tax deductions and returns.)

While personal exemption is optional providing the taxable person the choice of paying taxes under the general rules subject-based exemption is obligatory by law. ${ }^{38}$ Subject-based exemption is tied to the basis of assessment. It applies to every taxable person in cases of the sales of products, providing services and product imports listed by the Act. Like personal exemption subject-based exemption grants tax exemption to the taxable person while preventing tax deductions and returns. ${ }^{39}$

From the wide range of subject-based exemptions a select few types of products and services related to agricultural law should be highlighted. ${ }^{40}$ These include the supply of a building or parts of a building and the land on which it stands that is supplied before the first occupation or the elapsed period after first occupation, between the operative date of the occupancy permit of the relevant authority and the date of supply is less than two years and the supply of land or part of land which has not been built on excluding the leasing or renting of a building site.

Taxpayers in the agricultural sector are subject to the general rule but different types of special activities are provided with an option for special taxation method. This section focuses on the rules of taxation applied to producers conducting agricultural activities (agricultural producers). The special regulations benefit the taxpayers in two areas: the taxpayer is exempted from tax obligations and the related administrational burdens, through the compensational charges

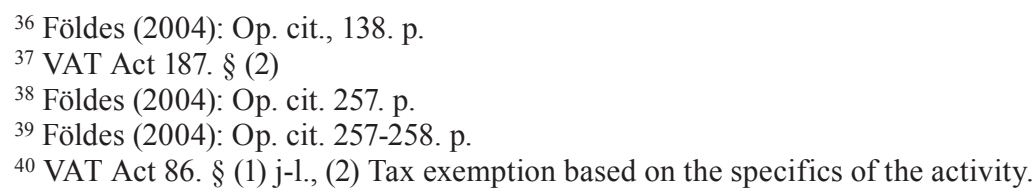


gain ,special budget assistance” which helps covering VAT costs related to their acquisitions. ${ }^{41}$ Agricultural activities are not subject to taxes but they don't allow for tax deduction and taxpayers have no return or accounting obligation regarding these activities. The law grants agricultural producers special legal status and also provides a legal definition from a VAT perspective.

A taxable person conducting agricultural activities shall mean one who fully or partially conducts agricultural activities, is qualified as microentrepreneurship or self-employment by the special law, is established inland or otherwise has their place of residence or habitual residence inland. Agricultural activity shall mean the production or processing of products listed by the VAT Act and services provided with the use of instruments of self-owned businesses. ${ }^{42}$

Compensational charges offset non-deducable taxes in cases of purchases from the conductor of the agricultural activity. Compensational charges are part of the consideration but not the buying price and have to be paid after the transaction by the buyer. ${ }^{43}$ The rate of the compensational charge is determined by the VAT Act at $12 \%$ for plants and herbal products, at $7 \%$ for livestock and animal products and also for providing services. Therefore compensational charges provide additional income for taxable persons conducting agricultural activities and the option to pass on VAT of acquisitions.

Compensational charges weigh only on the end consumer since the recipient has the option to deduct the VAT.

\section{SPECIAL LEVY REGULATIONS RELATED TO AGRICULTURAL ACTIVITIES AND ARABLE LAND}

Legislation acknowledges the problem of the dual nature of arable lands: it shouldn't simply be regarded as property since it is also a tool of production and thus a source of livelihood for the farmer. Subsequently levies favor transfer of property (be it free of charge or onerous) to preserve the continuity of management. ${ }^{44}$ The law prefers furthermore the free of charge transfer of necessary tools of farming along with the arable land.

In cases of gift and inheritance levies (free of charge transfers of property) tax law preference manifests in the form of tax exemptions and benefits. Transfers

${ }^{41}$ VAT Act 197-253. $\S$

42 VAT Act 198. § a-c. Sections I and II of Appendix 7 of the Act list all the products and services in the field of agricultural activities (e.g. living plants, livestock, animal products, food products from the processing of agricultural products, field work, packing and storage of agricultural products).

${ }^{43}$ VAT Act 201-202. §.

${ }^{44}$ Act XCIII.of 1990 on 
of arable lands (like with all other forms of property) are exempt from levies if the acquirer is the lineal relative or the surviving spouse of the deceased. ${ }^{45}$

Preferences for arable lands have a more narrow range and regulations operate with the method of full exemption instead. The inheritor of the arable land or its intangible property gains the benefit of having to pay only half the amount of the regular inheritance levy. If the inheritor is registered as a family estate farmer, he's only obligated to pay a quarter of the original amount. A similar regulation is in effect regarding the gifting of arable lands and their intangible properties: the amount of the levy to be paid is halved.

The transfer of property is fully exempt from levies in several cases of the gifting and inheritance of arable lands and their intangible properties. The transfer of management rights to the manager of state-owned environmentally protected areas is exempt. The law also exempts the inheritor if he transfers the inherited arable lands to a fellow inheritor registered as a family estate farmer. Furthermore, acquiring arable lands and their intangible properties by gifting is also exempt if the acquirer is a private entrepeneur, small-scale agricultural producer, family estate farmer and if the acquisition takes place as a requirement for homestead conveyancing support.

Unique types of homestead conveyancing exemptions can be found in the regulations of gifting and the free of charge transfer of intangible property. Private entrepeneurs, small-scale agricultural producers or family estate farmers are exempted from the levy if they acquire the arable land, the homestead, buildings or movable property items necessary for agricultural production from close relatives. ${ }^{46}$

The latter type of exemption applies to onerous tranfers of these types of properties, too. Generally transfers of property may only benefit from full exemptions rules of reduced levies and other preferences do not apply. Exempt is, however, the acquisiton of leasehold, acquisiton of property through voluntary land exchange for the purpose of land consolidation and the establishment of usufruct and use rights. The Levies Act grants levy exemption for the onerous acquisition of arable land by farmers if the legal requirements are met. These requirements include an obligation to use the land for agricultural or forestry purposes as a private entrepreneur, small-scale agricultural producer or family estate farmer for 5 years 12 months after the emergence of the levy payment obligation. It is also required to refrain from transferring the property or establishing any intangible property rights on it. ${ }^{47}$ Should the requirements be violated the law sanctions the acquirer by doubling the amount of the levy. ${ }^{48}$

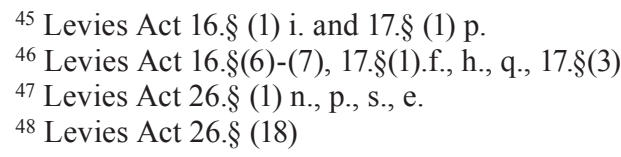




\section{SUMMARY}

Food production and rural development are strategic objectives of every government due to constant population growth and the increase of food product prices. A large part of the funds of the European Union flow into these sectors. It is important, however, for the legislator to help keeping the sector stable and provide access to quality food products for low income consumers.

It is easy to see while overviewing tax law regulations that the highest tax preferences are granted to agricultural producers, family estate farmers, and smallscale entrepreneurs. Small-scale agricultural producers conduct agricultural activities to secure additional income by using their own tools and workforce while practicing another (main) profession. These small farms are a highly important source of income for the rural population and fill a significant role in certain segments of food production, e.g. fruit and vegetable production and small-scale livestock production.

The tax law system of Hungary has been shifting from income taxes towards turnover taxes reducing income tax rates while increasing the rates for consumer taxes. (The rate of the personal income tax is $15 \%$ for private citizens and $9 \%$ for companies. The general rate of VAT is $27 \%$ but in some cases special rates apply.) Tax rates for food products had therefore have to be changed: by reducing them prices for food products also decreased.

The significance of the Levies Act lies in making it possible for relatives to conduct agricultural activities on gifted or inherited lands without high tax burdens and ensuring that arable lands are acquired by professional producers with the intent of agricultural production instead of investors through exemptions and preferences. 
Др Золиман Б. Нађ, ванредни иррофесор

Универзийей у Мищколиу

Правни факулиетеи

jogdrnz@uni-miskolc.hu

\section{Мађарско пореско законодавство о земљишту и пољопривредној делатности}

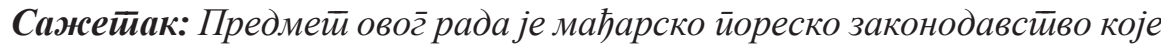
се односи на йољойривредну делайности и обрадиво землишиее. Рад се фокусира само на йри йореска облика, како због̄ обима рада, йако и због̄ чињенице да они у највећој мери одражавају сиеиијални сйайус обрадивог̄ земљи-

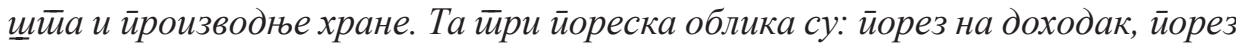

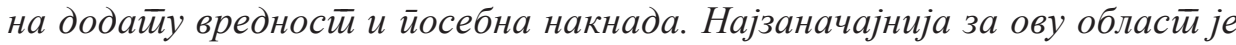
регуулайива йосвећена йорезу на доходак, јер овај йорески облик нуди могуућностии за разнолико регулисање йољойривредне делайностии, док је йреостиала два йореска облика уг̄лавном йоиииомажу сиечијалном регуулаииивом и йореским ослобођенима и олакщицама.

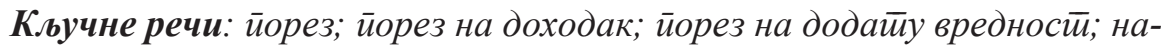
кнада; йољойривредник-йредузетиник; ,ммали“ ииољойривредник; йореско ослобођење; иореске олакщиие.

Датум пријема рада: 14.09.2017. 